\title{
Pengaruh Biostimulan dalam Memperlambat Aktivitas Senesen Bidang Sadap Tanaman Karet Terserang Penyakit Kering Alur Sadap di Kecamatan Gelumbang Kabupaten Muara Enim
}

\author{
Risal Latutoibin ${ }^{*}$ dan Suwandi ${ }^{2}$ \\ ${ }^{1}$ Program Studi Ilmu Tanaman, Fakultas Pertanian, Universitas Sriwijaya, J1. Padang Selasa No. \\ 524, Bukit Besar 30139, Palembang, Sumatera Selatan, Indonesia \\ 2 Departemen Hama dan Penyakit Tumbuhan, Fakultas Pertanian, Universitas Sriwijaya, \\ Indralaya 30862, Sumatera Selatan \\ *Alamat korespondensi: risal.latutoibin@gmail.com
}

\begin{tabular}{lr}
\hline \multicolumn{2}{c}{ INFO ARTIKEL } \\
\hline Diterima: & $26-02-2021$ \\
Direvisi: & $10-05-2021$ \\
Dipublikasi: $11-08-2021$
\end{tabular}

Keywords: Rubber, Tapping Panel Dryness, Biostimulant, Senescence Delay

Kata Kunci:

Karet, Biostimulan, KAS, Pelambatan Senesen

\section{ABSTRACT/ABSTRAK}

\section{Effect of Biostimulant to Delay the Senescence Activity of the Rubber Tapping Area Infected by Tapping Panel Dryness Disease at Gelumbang District, Muara Enim Regency}

One of the causes of declining rubber production is interference by the Tapping Panel Dryness (TPD). TPD triggered by an imbalance between regeneration latex in the latex vessels through excessive tapping (over exploitation) or physiological fatigue. The objective of this research was to study the senescence delay activity and latex dry weight of TPD affected tree and its response to a biostimulant application. The research was conducted at Tambangan Kelekar Village, Gelumbang District, Muara Enim Regency and Phytopathology Laboratory, Department of Plant Pests and Diseases Faculty of Agriculture, University of Sriwijaya from December 2016 to February 2017. This study consisted of 3 separated experiments, firstly experiment on healthy tree, secondly on partially TPD tree, and thirdly on totally TPD tree. Each experiment was arranged in a randomized block design with two treatments of biostimulant (formula $\mathrm{M}$ and S) and one control treatment. Each formula was treated on ten trees as replication. The result showed senescence activity delay of bark methanol extract collected from tapping panel was varied and not associated with the plant health. TPD drastically reduced the latex dry weight with $75,6 \%$ and $98 \%$ losses from partial and total TPD, respectively. Both senescence activity delay and latex dry weight were not significantly affected by biostimulant applications.

Salah satu penyebab menurunnya produksi karet adalah gangguan kering alur sadap (KAS). KAS dipicu oleh ketidakseimbangan antara regenerasi lateks di dalam pembuluh lateks dengan pengambilannya melalui penyadapan yang berlebihan atau kelelahan fisiologis. Tujuan dari penelitian ini adalah untuk mengetahui pengaruh aplikasi biostimulan dalam memperlambat aktivitas senesen bidang sadap tanaman karet yang terserang penyakit kering alur sadap. Penelitian dilaksanakan di kebun karet Desa Tambangan Kelekar Kecamatan Gelumbang Kabupaten Muara Enim dan Laboratorium Fitopatologi, Jurusan Hama dan Penyakit Tumbuhan Fakultas Pertanian Universitas Sriwijaya pada bulan Desember 2016 sampai Februari 2017. Penelitian terdiri dari 3 percobaan terpisah, 
percobaan pertama pada pohon sehat, kedua pada pohon terserang KAS parsial, dan yang ketiga pada pohon terserang KAS total. Setiap percobaan disusun dalam rancangan acak kelompok (RAK) dengan 2 perlakuan yaitu biostimulan (formula M dan S) dan satu perlakuan kontrol. Setiap formula dioles pada 10 pohon sebagai ulangan. Hasil penelitian menunjukkan bahwa aktivitas pelambatan senesen ekstrak metanol kulit tanaman yang dikumpulkan dari panel bidang sadap ialah sangat beragam dan tidak terkait dengan kesehatan tanaman. Penyakit KAS menyebabkan berat kering lateks menurun drastis yaitu dengan kehilangan hasil 75,6 dan 98\% untuk tanaman terserang KAS parsial dan total. Tingkat pelambatan senesen dan berat kering lateks tanaman karet terserang KAS tidak dipengaruhi secara nyata oleh aplikasi biostimulan.

\section{PENDAHULUAN}

Tanaman karet (Hevea brasiliensis Muell. Arg.) merupakan salah satu tanaman tahunan yang dapat menghasilkan lateks (Aminah dkk., 2016). Karet adalah salah satu komoditas pertanian penting di Indonesia selain kelapa sawit (Andriani et al., 2019). Estimasi luas lahan karet rakyat pada tahun 2020 mencapai 3,2 juta hektar dengan total produksi 3 juta ton (Dirjen Perkebunan, 2019). Pengembangan perkebunan karet yang tepat dapat memberikan pengaruh positif dalam meningkatkan laju perkembangan ekonomi nasional, yaitu sebagai salah satu sumber devisa negara, sekaligus berperan dalam pelestarian fungsi lingkungan hidup (Boerhendhy \& Agustina, 2013).

Dalam perkembangannya, tanaman karet memiliki beberapa masalah selama masa produksinya (Marampa \& Maskan, 2014). Penyakit pada tanaman karet merupakan salah satu faktor pengganggu yang penting dibandingkan gangguan lainnya, bahkan adanya penyakit dapat menggagalkan suatu usaha pertanaman (Arifsyah \& Sindar, 2019). Salah satu penyebab menurunnya produksi tanaman karet adalah gangguan kering alur sadap (KAS) (Sulaiman et al., 2018; Nugawela \& Wijesuriya, 2020). Penyakit ini dipicu oleh ketidakseimbangan regenerasi lateks yang berada di dalam pembuluh lateks dengan pengambilannya melalui penyadapan (Arja \& Supijatno, 2018). Kerugian produksi sebagai akibat dari serangan penyakit ini diperkirakan mencapai $12 \%$ sampai 20\% (Okoma et al., 2011). Apabila kondisi karet sudah sangat parah, maka dapat berakibat tidak keluarnya lateks.

Kandungan unsur hara makro dan mikro pada tanaman terserang KAS lebih rendah daripada tanaman normal (Andriyanto \& Tistama, 2014).
Pemberian nutrisi dan zat pengatur tumbuh yang tepat terbukti dapat mengatasi serangan KAS pada tanaman karet (Anggraini dkk., 2017). Suwandi et al., (2018) melaporkan tanaman karet yang terserang KAS parsial dapat diatasi dengan penggunaan fermentasi ekstrak kompos dalam waktu 2 bulan. Fermentasi ekstrak kompos tersebut diperoleh dari kulit udang yang mengandung N, P, K, mikronutrien, dan asam amino lebih rendah, sehingga formula ini tergolong ke dalam biostimulan. Formula biostimulan ini dapat mengendalikan tanaman karet terserang KAS namun tidak untuk penyakit KAS yang lebih parah.

Tanaman karet yang mengalami stress diketahui memiliki kandungan etilen yang tinggi. Etilen merupakan hormon yang dapat mempercepat aktivitas senesen (Iqbal et al., 2017). Sitokinin adalah zat pengatur tumbuh yang mampu menunda senesen pada tingkat sel dan jaringan tanaman (Zwack \& Rashotte, 2013; Talla et al., 2016). Penelitian ini bertujuan untuk mengamati aplikasi biostimulan dalam memperlambat aktivitas senesen tanaman karet yang terserang KAS yang terus menerus disadap.

\section{BAHAN DAN METODE}

Penelitian dilaksanakan di kebun karet Desa Tambangan Kelekar, Kecamatan Gelumbang, Kabupaten Muara Enim, Provinsi Sumatera Selatan, Indonesia. Penelitian dilaksanakan pada bulan Desember 2016 sampai Mei 2017. Tanaman yang digunakan pada penelitian ini adalah tanaman yang memiliki umur tidak lebih dari 13 tahun. Jumlah dari keseluruhan sampel yaitu 90 pohon dengan keterangan 30 pohon sehat, 30 pohon mengalami KAS parsial (sebagian), 30 pohon mengalami KAS total (Gambar 1). 
Terdapat dua biostimulan berjenis larutan yang digunakan dalam penelitian ini yaitu biostimulan formula M dan S. Biostimulan formula $\mathrm{M}$ mengandung lisin $184 \mathrm{ppm}$, asam amino glisin $365 \mathrm{ppm}$, asam aspartat $232 \mathrm{ppm}$, asam glutamat 170 ppm, leusin 186 ppm dan 132 ppm valin. Biostimulan formula $\mathrm{M}$ juga mengandung total asam lemak $40 \mathrm{~g} / \mathrm{l}$ dan asam lemak omega 6 4,5 g/l.
Sementara biostimulan formula $S$ mengandung asam lemak 23,8 g/l, asam lemak omega $64,3 \mathrm{~g} / \mathrm{l}$ dan asam amino yang sama dengan formula biostimulan M. Data yang didapat dianalisis menggunakan rancangan acak kelompok (RAK) dengan 2 perlakuan yaitu biostimulan (formula $\mathrm{M}$ dan $\mathrm{S}$ ) dan satu perlakuan kontrol.
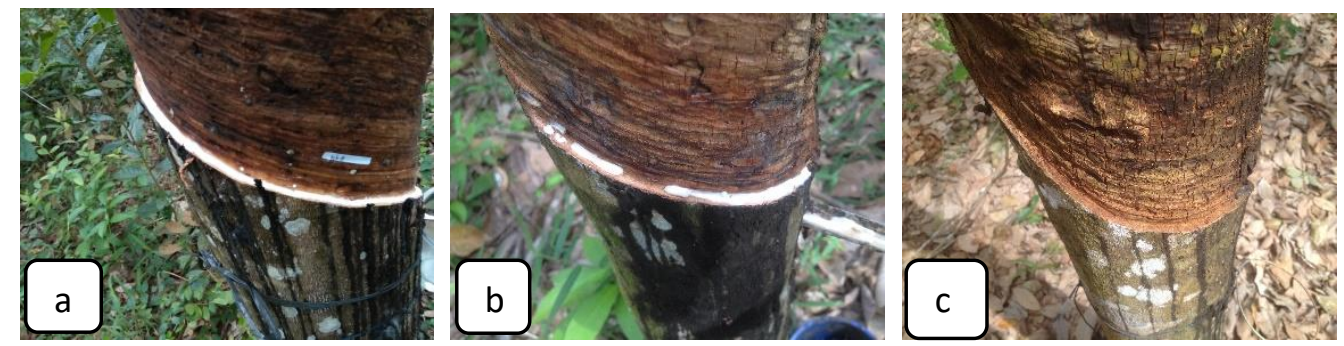

Gambar 1. Kondisi tanaman yang digunakan dalam penelitian

(a) tanaman sehat, (b) tanaman terserang KAS parsial, dan (c) tanaman KAS total.

\section{Aplikasi Biostimulan}

Biostimulan diaplikasikan pada ketiga panel bidang sadap tanaman. Sebelum diaplikasikan, dilakukan pengerokan pada kulit luar batang dengan menggunakan parang atau arit pada $15 \mathrm{~cm}$ dari alur sadap untuk tanaman sakit dengan kategori parsial dan kategori total, sedangkan pada tanaman yang sehat pengerokan batang tidak dilakukan. Pengerokan batang diharapkan dapat membuat cairan biostimulan lebih cepat meresap ke dalam bidang sadap.

Batang karet yang telah dikerok diolesi dengan masing-masing formula biostimulan dengan menggunakan kuas. Bidang sadap yang diberi perlakuan berada $7,5 \mathrm{~cm}$ di atas dan di bawah alur sadap untuk tanaman sakit KAS parsial dan KAS total. Perlakuan pada tanaman sehat dilakukan sekitar $15 \mathrm{~cm}$ di bawah alur sadap. Perlakuan kontrol dilakukan dengan mengoleskan air. Masing- masing perlakuan dilakukan sebanyak 2 kali dengan interval 1 bulan.

\section{Pengambilan dan Ekstraksi Sampel}

Setelah 2 minggu dari masa aplikasi biostimulan, semua sampel disadap untuk diambil kulit bekas sadapnya. Kulit bekas sadap pada masingmasing pohon kemudian dikumpulkan lalu dimasukkan ke dalam plastik klip dan diberi label berdasarkan perlakuan. Sampel dimasukkan ke dalam ice box selanjutnya dibawa ke laboratorium Fitopatologi Program Studi Proteksi Tanaman Universitas Sriwijaya untuk dilakukan analisis.

Kulit bidang sadap ditumbuk sampai berbentuk serbuk lalu ditimbang seberat $250 \mathrm{~g}$ (Gambar 2) kemudian direndam selama 24 jam dalam $1 \mathrm{ml}$ metanol untuk mengekstraksi bahan organik. Metanol selanjutnya dikeringanginkan selama 72 jam. Endapan ekstrak selanjutnya dilarutkan dalam $1 \mathrm{ml}$ aquades.
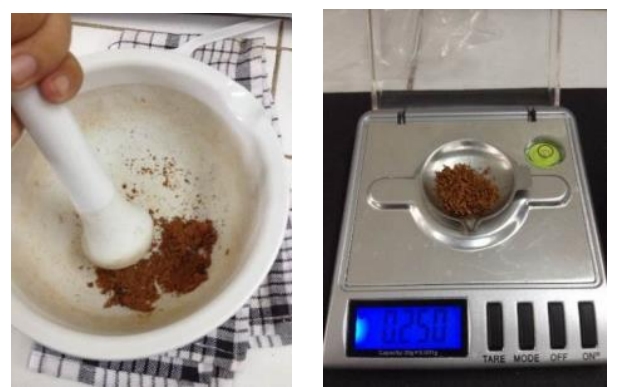

Gambar 2. Aktivitas penumbukan dan penimbangan sampel 
Aktivitas pelambatan senesen dihitung sebagai persentase dari jumlah total klorofil daun jagung berumur 2 minggu yang direndam pada ekstrak metanol kulit bekas sadap selama 4 hari dibagi jumlah total klorofil daun jagung berumur 2 minggu yang direndam pada akuades (tanpa ekstrak metanol) (Robson et al., 2004). Ekstrak metanol kulit sadapan terlebih dahulu diencerkan menjadi konsentrasi 30\% sebelum pengujian.

Daun jagung yang telah berumur 2 minggu dipotong dengan bagian pangkal, tengah, dan bagian ujung $5 \mathrm{~cm}$, setelah dipotong daun kemudian dimasukkan ke dalam tabung reaksi. Potongan daun jagung bagian pangkal daun yang tersentuh air di tabung reaksi setelah itu ditutup dengan parafilm. Tabung reaksi yang terisi daun tersebut kemudian diletakkan di tempat yang gelap selama 4 hari. Setiap sampel diuji menggunakan tiga buah daun jagung sebagai ulangan. Setelah 4 hari, klorofil a dan b dari sampel daun diekstraksi dengan cara daun dipotong kecil-kecil kemudian dimasukkan kedalam botol mikrotube yang ditambahkan dengan $1 \mathrm{ml}$ aceton $80 \%$ lalu disimpan dalam kulkas selama 2 hari. Klorofil dihitung berdasarkan absorbansi pada panjang gelombang 645 dan $663 \mathrm{~nm}$ (Prastyo \& Laily, 2015).

\section{Bobot Kering Lateks}

Kadar karet kering dihitung dengan menggunakan lateks dry rubber standard laboratory method (Sari \& Fatkhurahman, 2015) dengan mengambil $10 \mathrm{~g}$ sampel lateks dari tiap parameter kesehatan tanaman (sehat, kas parsial dan total) yang dibekukan dengan ditetesi larutan asam asetat yang dicampur dengan alkohol 75\% dengan perbandingan $1 \mathrm{ml}: 19 \mathrm{ml}$ hingga lateks membeku.

$$
\text { Berat Kering Lateks }=\frac{\text { kadar karet kering }}{100} \times \text { Berat }
$$

\section{Aktivitas Pelambatan Senesen}

Aktivitas pelambatan senesen dihitung sebagai persentase dari jumlah total klorofil daun jagung berumur 2 minggu yang direndam pada ekstrak metanol kulit bekas sadap selama 4 hari dibagi jumlah total klorofil daun jagung berumur 2 minggu yang direndam pada akuades (tanpa ekstrak metanol). Rumus :

$$
\mathrm{PS}=\left(1-\frac{b-a}{b} \times 100\right)
$$

\section{Keterangan :}

PS = pelambatan senesen.

a = jumlah total klorofil daun jagung berumur 2 minggu yang direndam pada ekstrak methanol kulit bekas sadap selama 4 hari.

$\mathrm{b} \quad=$ jumlah total klorofil daun jagung berumur 2 minggu yang direndam pada akuades (tanpa ekstrak metanol) selama 4 hari.

\section{HASIL DAN PEMBAHASAN}

\section{Pengujian Biostimulan pada Tanaman Sakit KAS Total}

Hasil analisis ragam menunjukkan bahwa perlakuan pengolesan biostimulan tidak berpengaruh nyata terhadap bobot kering lateks tanaman sakit kering alur sadap total. Saat 2 bulan setelah aplikasi, bobot kering lateks pada tanaman sakit kering alur sadap total terdapat peningkatan namun tidak signifikan (Gambar 1).

Tabel 1. Bobot kering lateks pada tanaman sakit kering alur sadap total yang diaplikasikan biostimulan

\begin{tabular}{ccc}
\hline \multirow{2}{*}{ Perlakuan Biostimulan } & \multicolumn{2}{c}{$\begin{array}{c}\text { Bobot kering lateks (g/pohon/sadap) } \\
\text { pada tanggal pengamatan }\end{array}$} \\
\cline { 2 - 3 } & 27 Desember 2016 (sebelum aplikasi) & 28 Februari 2017 (setelah aplikasi) \\
\hline Kontrol & - & 0,30 \\
Formula M & - & 2,35 \\
Formula S & - & 0,43 \\
\hline$P$ anova & - & $0,313^{\text {tn }}$
\end{tabular}

Keterangan: ${ }^{\text {tn }}=$ tidak berpengaruh nyata pada $\mathrm{P}<0,05$

Hasil analisis ragam menunjukkan bahwa perlakuan pengolesan biostimulan tidak berpengaruh nyata terhadap aktivitas pelambatan senesen pada tanaman sakit kering alur sadap total.
Saat 2 bulan setelah aplikasi, aktivitas pelambatan senesen pada tanaman sakit kering alur sadap total cenderung menurun dari bulan sebelumnya (Tabel 2). 
Tabel 2. Aktivitas pelambatan senesen pada tanaman sakit kering alur sadap total yang diaplikasikan biostimulan

\begin{tabular}{ccc}
\hline \multirow{2}{*}{ Perlakuan Biostimulan } & \multicolumn{2}{c}{$\begin{array}{c}\text { Aktivitas pelambatan sense (\%) } \\
\text { pada tanggal pengamatan }\end{array}$} \\
\cline { 2 - 3 } & 27 Desember 2016 (sebelum aplikasi) & 28 Februari 2017 (setelah aplikasi) \\
\hline Kontrol & 47,93 & 24,32 \\
Formula M & 40,35 & 28,05 \\
Formula S & 42,29 & 10,72 \\
\hline$P$ anova & $0,506^{\mathrm{tn}}$ & $0,155^{\mathrm{tn}}$ \\
\hline
\end{tabular}

Keterangan: ${ }^{\text {tn }}=$ tidak berpengaruh nyata pada $\mathrm{P}<0,05$

\section{Pengujian Biostimulan pada Tanaman Sakit KAS Parsial}

Hasil analisis ragam menunjukkan bahwa perlakuan pengolesan biostimulan tidak berpengaruh nyata terhadap bobot kering lateks tanaman sakit kering alur sadap parsial. Saat 2 bulan setelah aplikasi, bobot kering lateks lebih tinggi dari pada bulan sebelumya. Bobot kering lateks, setelah aplikasi cenderung lebih tinggi pada perlakuan biostimulan formula M dan S (Tabel 3).

Tabel 3. Bobot kering lateks pada tanaman sakit kering alur sadap parsial yang diaplikasikan biostimulan

\begin{tabular}{ccc}
\hline \multirow{2}{*}{ Perlakuan Biostimulan } & \multicolumn{2}{c}{ Bobot kering (g/pohon/sadap) pada tanggal pengamatan } \\
\cline { 2 - 3 } & 27 Desember 2016 (sebelum aplikasi) & 28 Februari 2017 (setelah aplikasi) \\
\hline Kontrol & 2,88 & 5,36 \\
Formula M & 2,16 & 7,01 \\
Formula S & 3,36 & 7,64 \\
\hline$P$ anova & $0,590^{\text {tn }}$ & $0,501^{\text {tn }}$ \\
\hline
\end{tabular}

Keterangan: ${ }^{\text {tn }}=$ tidak berpengaruh nyata pada $\mathrm{P}<0,05$

Hasil analisis ragam menunjukkan bahwa senesen pada tanaman sakit kering alur sadap parsial perlakuan pengolesan biostimulan tidak cenderung meningkat saat setelah aplikasi berpengaruh nyata terhadap aktivitas pelambatan biostimulan dibandingkan sebelum aplikasi. Pada senesen pada tanaman sakit kering alur sadap parsial tanaman kontrol aktivitas pelambatan senesen saat 2 bulan setelah aplikasi. Aktivitas pelambatan terjadi penurunan dari bulan sebelumnya (Tabel 4).

Tabel 4. Aktivitas pelambatan senesen pada tanaman karet sehat yang diaplikasikan biostimulan

\begin{tabular}{ccc}
\hline \multirow{2}{*}{ Perlakuan Biostimulan } & \multicolumn{2}{c}{$\begin{array}{c}\text { Aktivitas pelambatan sense (\%) } \\
\text { tanggal pengamatan }\end{array}$} \\
\cline { 2 - 3 } & 27 Desember 2016 (sebelum aplikasi) & 28 Februari 2017 (setelah aplikasi) \\
\hline Kontrol & 71,82 & 45,21 \\
Formula M & 25,69 & 54,9 \\
Formula S & 15,51 & 37,76 \\
\hline$P$ anova & $0,0001^{*}$ & $0,276^{\mathrm{tn}}$ \\
\hline
\end{tabular}

Keterangan: ${ }^{\mathrm{tn}}=$ tidak berpengaruh nyata pada $\mathrm{P}<0,05$

\section{Pengujian Biostimulan pada Tanaman Sehat}

Hasil analisis ragam menunjukkan bahwa perlakuan pengolesan biostimulan tidak berpengaruh nyata terhadap bobot kering lateks tanaman sehat. Saat 2 bulan setelah aplikasi bobot kering lateks lebih tinggi dari pada bulan sebelumnya. Pada perlakuan biostimulan formula M, bobot kering lateks lebih rendah dari bulan sebelumnya, sebaliknya untuk formula $\mathrm{S}$ terjadi peningkatan bobot kering (Tabel 5). 
Tabel 5. Bobot kering lateks pada tanaman sehat yang diaplikasikan biostimulan

\begin{tabular}{ccc}
\hline \multirow{2}{*}{ Perlakuan Biostimulan } & \multicolumn{2}{c}{$\begin{array}{c}\text { Bobot kering lateks (g/pohon/sadap) } \\
\text { tanggal pengamatan }\end{array}$} \\
\cline { 2 - 3 } & 27 Desember 2016 (sebelum aplikasi) & 28 Februari 2017 (setelah aplikasi) \\
\hline Kontrol & 16,9 & 18,18 \\
Formula M & 18,88 & 16,28 \\
Formula S & 11,05 & 14,98 \\
\hline$P$ anova & $0,231^{\text {tn }}$ & $0,565^{\text {tn }}$
\end{tabular}

Keterangan: ${ }^{\text {tn }}=$ tidak berpengaruh nyata pada $\mathrm{P}<0,05$

Hasil analisis ragam menunjukkan bahwa perlakuan pengolesan biostimulan tidak berpengaruh nyata terhadap aktivitas pelambatan senesen pada tanaman karet sehat. Pada saat 2 bulan setelah aplikasi, aktivitas pelambatan senesen tanaman karet sehat yang diaplikasi formula $\mathrm{M}$ dan $\mathrm{S}$ mengalami penurunan aktivitas senesen. Akan tetapi, aktivitas pelambatan sense pada perlakuan kontrol mengalami peningkatan (Tabel 6).

Tabel 6. Aktivitas pelambatan senesen pada tanaman karet sehat yang diaplikasikan biostimulan

\begin{tabular}{ccc}
\hline \multirow{2}{*}{ Perlakuan Biostimulan } & \multicolumn{2}{c}{$\begin{array}{c}\text { Aktivitas pelambatan sense (\%) } \\
\text { tanggal pengamatan }\end{array}$} \\
\cline { 2 - 3 } & 27 Desember 2016 (sebelum aplikasi) & 28 februari 2017 (setelah aplikasi) \\
\hline Kontrol & 17,66 & 24,98 \\
Formula M & 84,89 & 52,71 \\
Formula S & 83,16 & 38,83 \\
\hline$P$ anova & $0,0001^{*}$ & $0,315^{\text {tn }}$ \\
\hline
\end{tabular}

Keterangan: ${ }^{\text {tn }}=$ tidak berpengaruh nyata pada $\mathrm{P}<0,05$

\section{Berat Kering Lateks Tanaman Sehat dan Sakit}

Pada pengamatan bulan pertama dan kedua berat kering lateks tanaman sehat lebih tinggi dari tanaman terserang KAS parsial dan KAS total (Gambar 3). Rata-rata berat kering lateks selama 2 bulan pengamatan yaitu 0,$51 ; 6,14$; dan 25,14 g/pohon/sadap, masing-masing untuk tanaman KAS total, parsial dan tanaman sehat. Dengan demikian, kehilangan hasil pada tanaman KAS total dan parsial ialah $98 \%$ dan $75,6 \%$.

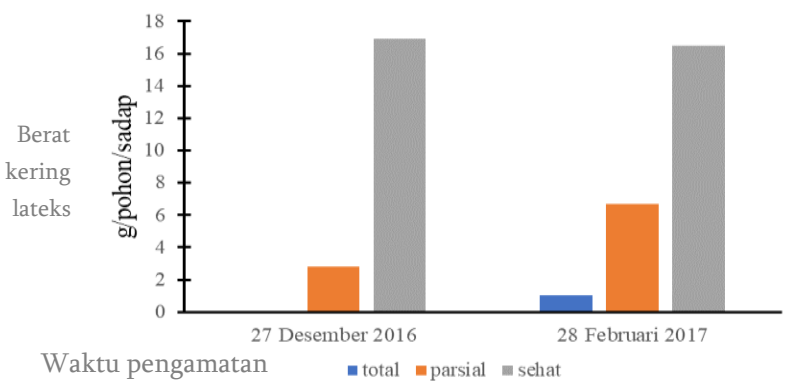

Gambar 3. Bobot kering lateks pada berbagai taraf kesehatan tanaman

Hasil penelitian menunjukkan bahwa pelambatan senesen pada tanaman sakit KAS total dan parsial adalah relatif sama yang nilainya lebih rendah dibandingkan dengan pelambatan senesen pada tanaman sehat. Rendahnya pelambatan senesen pada tanaman terserang KAS diduga berhubungan dengan tingginya aktivitas spesies oksigen reaktif (ROS). Menurut Putranto et al., (2015) tanaman terserang KAS menghasilkan ROS yang melimpah akibat cekaman fisiologis yang berkelanjutan. Semakin tinggi aktivitas pelambatan senesen maka diduga aktivitas sitokinin atau kemampuan 
peremajaan jaringan tanaman semakin baik. Sitokinin adalah senyawa turunan adenin dan berperan dalam pengaturan pembelahan sel dan morfogenesis (Widiastoety, 2016). Sitokinin berguna untuk merangsang terbentuknya tunas, merangsang pembentukan akar dan batang, serta memacu pertumbuhan kloroplast dan sintesis protein dan meningkatkan laju sintesis protein (Admaja \& Sulistyowati, 2014).

Hasil penelitian menunjukkan bahwa kehilangan berat kering lateks pada tanaman terserang KAS parsial adalah 75,6\%. Pada tanaman terserang KAS total persentase kehilangan berat kering lateks ialah 98\%. Berat kering lateks pada tanaman yang terserang kering alur sadap (KAS) total dapat diamati pada pengamatan kedua baik pada tanaman yang dioles biostimulan ataupun tanaman kontrol. Hal ini menunjukan bahwa tanaman yang terserang KAS mulai mengalami penyembuhan jika tanaman dibiarkan dengan tidak disadap (Nugrahani et al., 2017). Dengan demikian, tanaman KAS total pada penelitian tergolong kepada KAS yang dapat pulih dan bukan tergolong Brown Bast. Kerusakan jaringan pembuluh lateks pada tanaman terserang KAS yang dapat pulih, belum bersifat permanen dan belum terjadi malformasi jaringan lateks.

Kerusakan permanen terjadi karena gangguan fisiologis yang menyebabkan tanaman tidak dapat mengeluarkan lateks setelah dilakukan penyadapan, hal ini merupakan pengaruh dari jaringan pembuluh lateks yang tersumbat. Pembuluh lateks berhubungan langsung terhadap hasil dari lateks (Woelan dkk., 2013). Tersumbatnya aliran lateks disebabkan oleh pembekuan lateks dan terbentuknya sel tilosoid dalam jaringan pembuluh lateks (Nugrahani et al., 2016). Sel tilosoid terbentuk karena terjadinya kerusakan membran lutoid yang mengakibatkan keluarnya serum dalam lutoid yang yang bersifat asam ke dalam pembuluh lateks sehingga partikel karet mengumpal. Gumpalan lateks tersebut akan direspon sel tanaman lain untuk membentuk jaringan tilosoid dan akan menyumbat seluruh aliran lateks.

Potensi peningkatan produksi dengan penggunaan stimulan bervariasi sesuai dengan kemampuan biosintesisnya. Menurut Herlinawati \& Kuswanhadi (2013) terdapat perbedaan respon tiap antara klon terhadap stimulan. Pada penelitian ini tidak menunjukkan adanya pengaruh pengolesan biostimulan dalam peningkatkan produksi lateks. Penggunaan stimulan tanpa memperhatikan karakteristik klon yang ditanam dapat menyebabkan kelelahan fisiologis (Atminingsih dkk., 2016). Pada tanaman KAS total, belum adanya respon peningkatkan produksi diduga karena waktu pengamatannya dilakukan dua bulan setelah aplikasi. Sinamo et al., (2015) melaporkan bahwa peningkatan produksi lateks baru dicapai setelah 5 bulan. Hasil yang sama juga dilaporkan oleh Suwandi et al., (2018) yang menunjukkan rendahnya pemulihan lateks KAS total pada dua bulan setelah aplikasi dan bahkan sampai sepuluh bulan setelah aplikasi biostimulan. Pada tanaman KAS parsial juga belum ditemukan adanya peningkatan produksi lateks setelah aplikasi biostimulan. Hal ini diduga karena pohon sakit tetap disadap secara berlebihan dan tidak diistirahatkan. Faktor pemicu stress atau kelelahan fisiologis masih berlangsung sehingga sulit dipulihkan. Pada percobaan menggunakan tanaman yang diistirahatkan dari penyadapan, perlakuan biostimulan dapat memulihkan produksi lateks mulai dari dua bulan setelah aplikasi (Suwandi et al., 2018).

Mengistirahatkan tanaman dalam kurun waktu tertentu merupakan konsep pemulihan bidang sadap yang dapat dilakukan, karena tanaman akan mengoptimalkan kembali bagian-bagian tanaman yang telah mengalami pelukaan (Robianto \& Supijatno, 2017). Hal ini sesuai dengan pernyataan Nugrahani et al., (2016) yang menyatakan bahwa pada tanaman KAS parsial, tanaman yang diperlakukan dengan istirahat sadap selama beberapa waktu (rest period) akan kembali sehat sehingga dapat disadap kembali. Sebaliknya tanaman yang mengalami KAS total, bidang sadap tidak dapat mengalirkan lateks seperti semula sebelum terjadi regenerasi kulit baru.

\section{SIMPULAN}

Aktivitas pelambatan senesen ekstrak metanol kulit tanaman yang dikumpulkan dari panel bidang sadap ialah sangat beragam dan tidak terkait dengan kesehatan tanaman. Penyakit KAS menyebabkan berat kering lateks menurun drastis yaitu dengan kehilangan hasil 75,6\% dan 98\% masing-masing pada tanaman terserang KAS parsial dan total. Tingkat pelambatan senesen dan berat kering lateks tanaman karet terserang KAS yang disadap terus-menerus tidak dipengaruhi secara nyata oleh aplikasi biostimulan.

\section{UCAPAN TERIMA KASIH}


\begin{tabular}{lcrr}
\multicolumn{2}{c}{ Kegiatan ini dibiayai } & Penelitian & Terapan \\
Unggulan & Universitas & Sriwijaya & no. \\
102/SP2H/LT/DPRM/IV/2017. & &
\end{tabular}

\section{DAFTAR PUSTAKA}

Admaja, W, H Sulistyowati, dan Sarbino. 2014. Pengaruh campuran hormon organik dan pupuk organik cair terhadap peningkatan daya tumbuh bibit stum mata tidur tanaman karet. Jurnal Perkebunan \& Lahan Tropika. 4(2): 18-21.

Aminah, EAM Zuhud, dan IZ Siregar. 2016. Pemanfaatan jelutung (Dyera spp.) oleh Suku Anak Dalam di Taman Nasional Bukit Dua Belas, Jambi. Media Konservasi. 21(2): 168173.

Andriani, E, S Gustaman, DR Saputra, E Kusnadi, Suheri, dan M Emo. 2019. Analisis Komoditas Ekspor 2012-2019 Sektor Pertanian, Industri, dan Pertambangan. Badan Pusat Statistik.

Andriyanto, M, dan R Tistama. 2014. Perkembangan dan upaya pengendalian Kering Alur Sadap (KAS) pada tanaman karet (Hevea brasiliensis). Warta Perkaretan. 33(2): 89.

Anggraini, U, Rosmayati, dan RIM Damanik. 2017. Aktivitas superoksida dismutase dan fisiologi lateks tanaman karet (Hevea brasiliensis Muell Arg.) PB260 dan RRIM 921 kering alur sadap parsial dengan pemberian zat pengatur tumbuh. Jurnal Agroekoteknologi. 5(3): 537545.

Arifsyah, dan A Sindar. 2019. Sistem Pakar diagnosa penyakit pohon karet dengan metode certainty factor. JISKA. 4(2): 94-100.

Arja, AR, dan Supijatno. 2018. Penyadapan tanaman karet (Hevea brasiliensis Mull-Arg.) di Perkebunan Karet Gurach Batu Estate, Asahan, Sumatera Utara. Buletin Agrohorti. 6(1): 1-9.

Atminingsih, JA Napitupulu, dan THS Siregar. 2016. Pengaruh konsentrasi stimulan terhadap fisiologi lateks beberapa klontanaman karet (Hevea Brasiliensis Muell ARG). Jurnal Penelitian Karet. 34(1): 13-24.

Boerhendhy, I, dan DS Agustina. 2013. Prospek pengembangan karet di wilayah daerah aliran sungai. Jurnal Litbang Pertanian. 32(4): 156165.

Dirjen Perkebunan. 2019. Statistik Perkebunan Indonesia 2018 - 2019 (D. Gartina \& R. L. L. Sukriya (eds.)). Sekretariat Direktorat
Jenderal Perkebunan.

Herlinawati, E, dan Kuswanhadi. 2013. Aktivitas Metabolisme beberapa klon karet pada berbagai frekuensi sadap dan stimulasi. Jurnal Penelitian Karet. 31(2): 110-116.

Iqbal, N, NA Khan, A Ferrante, A Trivellini, A Francini, and MIR Khan. 2017. Ethylene role in plant growth, development and senescence: interaction with other phytohormones. Frontiers in Plant Science. 8.

Marampa, YP, dan AF Maskan. 2014. Analisis kelayakan finansial budidaya tanaman karet (Hevea brasiliensis) skala rakyat di Kampung Tering Seberang Kecamatan Tering Kabupaten Kutai Barat. Jurnal AGRIFOR. 13(1): 231-240.

Nugawela, RCWMRA, and BW Wijesuriya. 2020. Impact of certain biological and environmental factors on the incidence of tapping panel dryness in Hevea Brasiliensis. Rubber Science. 33(3): 253-261.

Nugrahani, MO, A Rouf, YBS Aji, T Widyasari, dan ND Rinojati. 2017. Kombinasi sistem sadap frekuensi rendah dan penggunaan stimulan untuk optimasi produksi dan penurunan biaya penyadapan di panel bo. Jurnal Penelitian Karet. 35(1): 59-70

Nugrahani, MO, A Rouf, I Berlian, dan H Hadi. 2016. Kajian Fisiologis kering alur sadap pada tanaman karet (Hevea brasiliensis). Warta Perkaretan. 35(2): 135-146.

Okoma, KM, K Dian., S Obouayeba, AAE Elabo, and ASP N'guetta. 2011. Seasonal variation of tapping panel dryness expression in rubber tree Hevea brasiliensis muell. arg. in Cote d'ivoire. Agriculture and Biology Journal of North America. 2(3): 559-569.

Prastyo, KA, dan AN Laily. 2015. Uji konsentrasi klorofil daun temu mangga (Curcuma mangga Val.), temulawak (Curcuma xanthorrhiza), dan temu hitam (Curcuma aeruginosa) dengan Tipe kertas saring yang berbeda menggunakan spektrofotometer. Seminar Nasional Konservasi dan Pemanfaatan Sumber Daya Alam.

Putranto, RA, E Herlinawati, M Rio, J Leclercq, P Piyatrakul, E Gohet, C Sanier, F Oktavia, J Pirrello, Kuswanhadi, and P Montoro. 2015. Involvement of ethylene in the latex metabolism and tapping panel dryness of Hevea brasiliensis. International Journal of Molecular Sciences. 16(8): 17885-17908. 
Robianto, dan Supijatno. 2017. Sistem penyadapan karet (Hevea brasiliensis Muell. Arg.) di Tulung Gelam Estate, Sumatera Selatan. Buletin Agrohorti. 5(2): 274-282.

Robson, PRH, IS Donnison, K Wang, B Frame, SE Pegg, A Thomas, and H Thomas. 2004. Leaf senescence is delayed in maize expressing the Agrobacterium IPT gene under the control of a novel maize senescence-enhanced promoter. Plant Biotechnology Journal. 2(2): 101-112.

Sari, IRJ, and JA Fatkhurahman. 2015. Review of determining dry rubber content on processing rubber sheet. Prosiding Seminar Nasional Kulit, Karet dan Plastik. 169-180.

Sinamo, H, Charloq, Rosmayati, dan Radite. 2015. Respon Produksi lateks dalam berbagai waktu aplikasi pada beberapa klon tanaman karet terhadap pemberian berbagai sumber hormon etilen. Jurnal Online Agroekoteknologi. 3(2): 542-551.

Sulaiman, Z, M Tengku, M Mohamed, M Yusoff, and A Samad. 2018. Overview of Brown bast syndrome of hevea overview of brown bast syndrome of Hevea Brasiliensis. PJSRR. 4(1): 25-30.

Suwandi, S, A Junita, S Suparman, A Umayah, A Hamidson, A Muslim, and C Irsan. 2018. Curative activity of watery fermented compost extract as a bark treatment against tapping panel dryness. The Open Agriculture Journal. 12(1): 74-83.

Talla, SK, M Panigrahy, S Kappara, P Nirosha, S Neelamraju, and R Ramanan. 2016. Cytokinin delays dark-induced senescence in rice by maintaining the chlorophyll cycle and photosynthetic complexes. Journal of Experimental Botany. 67(6): 1839-1851.

Widiastoety, D. 2016. Pengaruh auksin dan sitokinin terhadap pertumbuhan planlet Anggrek Mokara. Jurnal Hortikultura. 24(3): 230.

Woelan, S, S Sayurandi, and SA Pasaribu. 2013. Karakter fisiologi, anatomi, pertumbuhan dan hasil lateks klon Irr Seri 300. Jurnal Penelitian Karet. 31(1): 1-12.

Zwack, PJ, and AM Rashotte. 2013. Cytokinin inhibition of leaf senescence. Plant Signaling and Behavior. 8(7): e24737. 